\title{
Application of Statistical Experimental Design and Surface Plot Technique to Optimize Oxygenated Apatite Synthesis
}

\author{
Soumia Belouafa $\mathbb{D D}^{1}{ }^{1}$ Hassan Chaair, ${ }^{2}$ and Khalid Digua ${ }^{2}$ \\ ${ }^{1}$ Laboratory of Biomolecules and Organic Synthesis, Faculty of Sciences Ben M'Sik, Hassan II University of Casablanca, \\ Casablanca, Morocco \\ ${ }^{2}$ Laboratory of Process and Environment Engineering, Faculty of Sciences and Technologies Mohammedia, \\ Hassan II University of Casablanca, Casablanca, Morocco \\ Correspondence should be addressed to Soumia Belouafa; sbelouafa@yahoo.fr
}

Received 5 March 2020; Revised 7 May 2020; Accepted 2 June 2020; Published 24 June 2020

Academic Editor: Tetsu Yonezawa

Copyright $\odot 2020$ Soumia Belouafa et al. This is an open access article distributed under the Creative Commons Attribution License, which permits unrestricted use, distribution, and reproduction in any medium, provided the original work is properly cited.

\begin{abstract}
This work deals with oxygenated apatite synthesis from calcium chloride and phosphoric acid using a wet precipitation method. An experimental design is applied to precise the influence of the synthesis parameters $(\mathrm{pH}$ of the reaction medium, atomic ratio $\mathrm{Ca} / \mathrm{P}$ of the reagents, concentration of the calcium solution $\left(\mathrm{Ca}^{2+}\right)$, temperature of the reaction medium $(\mathrm{T})$, and duration of the reaction (D)) on the chemical composition $\left(\mathrm{Ca} / \mathrm{P}\right.$ molar ratio, $\% \mathrm{O}_{2}$, and $\left.\% \mathrm{O}_{2}{ }^{2-}\right)$. An empirical model was developed and validated by applying the ANOVA analysis incorporating the interaction effects of all parameters and optimized using the response surface methodology. A reproducible synthesis of more oxygenated apatite with speed of dissolution adaptable to that of the osseous neoformation and allowing a progressive diffusion of oxygenated species $(\mathrm{Ca} / \mathrm{P}=1.575)$ is attained.
\end{abstract}

\section{Introduction}

Oxygenated apatites based on calcium phosphate have a wide range of potential applications for bone and dental substitutes because of their antibacterial properties, which make them able to limit the proliferation of microorganisms at the site of implantation [1-3]. These properties are due to the oxygenated species (molecular oxygen: $\mathrm{O}_{2}$, and peroxide ions: $\mathrm{O}_{2}{ }^{2-}$ ) contained in the channels of the apatite structure [1-3]. These species are liberated in the living environment either by progressive dissolution of the material or by chemical exchange with the living environment [1].

In the last years, various batch precipitation methods oxygenated apatites have been developed [1-3]. The aim of this work is to obtain a more oxygenated apatite with the speed of dissolution adaptable to that of the osseous neoformation and allowing a progressive diffusion of oxygenated species $(\mathrm{Ca} /$ $\mathrm{P}=1.575$ ) [4]. The difficulty is the factors governing the precipitation that are usually not precisely controlled $[5,6]$ (e.g., $\mathrm{pH}$ of reaction medium, atomic ratio $\mathrm{Ca} / \mathrm{P}$ of the reagents, concentration of the calcium solution $\left(\mathrm{Ca}^{2+}\right)$, temperature of reaction medium $(\mathrm{T})$, and duration of reaction $(\mathrm{D}))$.
On this basis, our work is concerned to modelize and optimize this synthesis process by applying the experimental design and response surface methodologies. These methodologies are essential in engineering to improve the performance of a manufacturing process. They are widely employed in the development of new processes. The application of experimental design and response surface techniques during the initial phase of process development can lead to improved process performance, less variability, shorter development time, and thus, reduced overall cost [7].

\section{Materials and Methods}

2.1. Powder Synthesis. The preparation of phosphocalcic oxygenated apatite was performed by the precipitation reaction with calcium and phosphate solutions. The calcium solution was prepared by adding calcium chloride $\left(\mathrm{CaCl}_{2}\right)$ in $250 \mathrm{~mL}$ of oxygenated water $(30 \%)$. The phosphate solution was prepared by adding phosphoric acid (84\%) in $250 \mathrm{~mL}$ of oxygenated water (30\%). The method of synthesis consists in putting the calcium solution into a reactor maintained at the temperature of synthesis. The $\mathrm{pH}$ was adjusted by manual 
addition of $\mathrm{NH}_{4} \mathrm{OH}$ solution $(d=0.92)$. Then, the orthophosphoric acid solution was poured into the reactor all at once. The reacting medium was kept under agitation for the duration of the reaction at the $\mathrm{pH}$ of synthesis. At the end, the suspension was vacuum filtered, washed with distilled water, dried in a desiccator and analysed.

2.2. Powder Characterization. X-ray diffraction analysis was carried out by means of a SEIFERT XRD $3000 \mathrm{P}$ using CuK radiation. For infrared absorption analysis, $1 \mathrm{mg}$ of the powdered sample was carefully mixed with $300 \mathrm{mg}$ of $\mathrm{KBr}$ and pelletised under vacuum. The pallets were analysed using a PerkinElmer 1600 FTIR spectrophotometer. Calcium, phosphorus, and the content of the oxygenated species were determined by wet chemical methods. Calcium was titrated by complexometry methods [8], the phosphorus content was analysed by colorimetry [9], molecular oxygen was determined by measuring the volume displaced during the acid dissolution of the powder [1], and the peroxide ions were titrated by manganometry methods [10].

2.3. Statistical Experiment Design. A central composite design, with two replicates at the center point, six experiments on the six axes, and sixteen experiments belonging to a $2^{5-1}$ factorial fractional design, was employed to evaluate the influence of the synthesis parameters $(\mathrm{pH}$ of the reaction medium, atomic ratio $\mathrm{Ca} / \mathrm{P}$ of the reagents, concentration of the calcium solution $\left(\mathrm{Ca}^{2+}\right)$, temperature of the reaction medium (T), and duration of the reaction (D)) on the chemical composition $\left(\mathrm{Ca} / \mathrm{P}\right.$ molar ratio, $\% \mathrm{O}_{2}$, and $\left.\% \mathrm{O}_{2}{ }^{2-}\right)$.

The statistical data treatment was accomplished through the JMP statistical software [11] in experimental design modulates. This program uses the one-way ANOVA table to analyze statistical data. ANOVA involves calculations of the some square (SS), degree of freedom (DF), and media square (MS) for the main effects, interactions, and residual part. Test $F$ (media square of effects/media square of residual) and significance factor $(P)$ are used to evaluate the significant effects. If the $F$ value for a given effect is higher than the $F$ value in the table, this effect is a significant one. Usually, the $F$ table used for significance level equals 0.05 . When the significance factor $(P)$ is used to evaluate the effects significance, this value must be lower than the significance level, so lower than $0.05[12,13]$.

The independent variables interval used in this work is shown in Table 1. They were selected based on a previous study of this synthesis process.

\section{Results and Discussion}

The influence of the synthesis variables, on the composition of the powders, evaluated through the experiment design can be seen in Table 2. The results in the form of analysis of variance (ANOVA) are given in Table 3. The significance factor $(P)$ values for all dependent variables were expressed as function of independent ones (Tables 4-6). The dependent variable has a significant influence when the significance factor $(\mathrm{P})$ is lower than 0.05 . Thus, the regression model
TABLE 1: Experimental range and level of independent variables.

\begin{tabular}{lcccccc}
\hline \multirow{2}{*}{ Variables } & \multirow{2}{*}{ Units } & \multicolumn{5}{c}{ Range and levels } \\
& & -1.3408 & -1 & 0 & 1 & 1.3408 \\
\hline$x_{1}=\mathrm{pH}$ & - & 6 & 6.25 & 7 & 7.75 & 8 \\
$x_{2}=\mathrm{Ca} / \mathrm{P}$ & - & 1.33 & 1.373 & 1.5 & 1.627 & 1.67 \\
$x_{3}=\left[\mathrm{Ca}^{2+}\right]$ & mol. $^{-1}$ & 0.516 & 0.533 & 0.582 & 0.631 & 0.648 \\
$x_{4}=\mathrm{T}$ & ${ }^{\circ} \mathrm{C}$ & - & 40 & - & 80 & - \\
$x_{5}=\mathrm{D}$ & $\mathrm{h}$ & - & 1 & - & 4 & - \\
\hline
\end{tabular}

The variables were coded according to the following equation: $X_{j}=\left(x_{j}-\overline{x_{j}}\right) / \Delta x$; T: temperature; $D$ : duration of the reaction.

TABle 2: Experimental design with results.

\begin{tabular}{|c|c|c|c|c|c|c|c|c|}
\hline \multirow{2}{*}{$\begin{array}{l}\text { Logical } \\
\text { order }\end{array}$} & \multicolumn{5}{|c|}{ Coded units of variables } & \multicolumn{3}{|c|}{ Responses } \\
\hline & $\mathrm{pH}$ & $\mathrm{Ca} / \mathrm{P}$ & {$\left[\mathrm{Ca}^{2+}\right]$} & $\mathrm{T}$ & $\mathrm{D}$ & $\mathrm{Ca} / \mathrm{P}$ & $\begin{array}{l}\% \\
\mathrm{O}_{2}\end{array}$ & $\% \mathrm{O}_{2}^{2-}$ \\
\hline 1 & -1 & -1 & -1 & -1 & 1 & 1.359 & 1.18 & 1.52 \\
\hline 2 & -1 & -1 & -1 & 1 & -1 & 1.300 & 1.13 & 2.94 \\
\hline 3 & -1 & -1 & 1 & -1 & -1 & 1.355 & 1.15 & 1.15 \\
\hline 4 & -1 & -1 & 1 & 1 & 1 & 1.452 & 1.18 & 2.89 \\
\hline 5 & -1 & 1 & -1 & -1 & -1 & 1.392 & 0.96 & 1.34 \\
\hline 6 & -1 & 1 & -1 & 1 & 1 & 1.430 & 1.18 & 2.46 \\
\hline 7 & -1 & 1 & 1 & -1 & 1 & 1.579 & 1.18 & 1.22 \\
\hline 8 & -1 & 1 & 1 & 1 & -1 & 1.543 & 1.12 & 1.23 \\
\hline 9 & 1 & -1 & -1 & -1 & -1 & 1.450 & 1.18 & 1.42 \\
\hline 10 & 1 & -1 & -1 & 1 & 1 & 1.541 & 1.15 & 1.45 \\
\hline 11 & 1 & -1 & 1 & -1 & 1 & 1.586 & 1.21 & 0.76 \\
\hline 12 & 1 & -1 & 1 & 1 & -1 & 1.540 & 1.13 & 0.96 \\
\hline 13 & 1 & 1 & -1 & -1 & 1 & 1.433 & 1.15 & 1.38 \\
\hline 14 & 1 & 1 & -1 & 1 & -1 & 1.595 & 1.24 & 2.28 \\
\hline 15 & 1 & 1 & 1 & -1 & -1 & 1.580 & 1.37 & 0.51 \\
\hline 16 & 1 & 1 & 1 & 1 & 1 & 1.624 & 1.18 & 0.45 \\
\hline 17 & -1.3408 & 0 & 0 & -1 & -1 & 1.440 & 1.18 & 0.84 \\
\hline 18 & 1.3408 & 0 & 0 & -1 & -1 & 1.610 & 1.40 & 1.23 \\
\hline 19 & 0 & -1.3408 & 0 & -1 & 1 & 1.551 & 1.16 & 0.72 \\
\hline 20 & 0 & 1.3408 & 0 & -1 & 1 & 1.584 & 1.15 & 0.99 \\
\hline 21 & 0 & 0 & -1.3408 & 1 & -1 & 1.487 & 1.21 & 3.01 \\
\hline 22 & 0 & 0 & 1.3408 & 1 & -1 & 1.541 & 1.12 & 1.48 \\
\hline 23 & 0 & 0 & 0 & 1 & 1 & 1.600 & 1.21 & 1.64 \\
\hline 24 & 0 & 0 & 0 & 1 & 1 & 1.590 & 1.21 & 1.63 \\
\hline
\end{tabular}

$\Delta \mathrm{Ca}=0.005, \Delta P=0.005, \Delta\left(\% \mathrm{O}_{2}\right)=0.02, \Delta\left(\% \mathrm{O}_{2}{ }^{2-}\right)=0.01$.

equations relating responses and synthesis parameters were developed and given in the following equations:

$$
\begin{aligned}
\widehat{\mathrm{Ca} / \mathrm{P}}= & 1.59+0.06 X_{1}+0.04 X_{2}+0.05 X_{3}+0.01 X_{4} \\
& +0.01 X_{5}-0.02 X_{2}^{2}-0.06 X_{3}^{2}-0.02 X_{1} X_{2} \\
& +0.01 X_{1} X_{4}-0.01 X_{1} X_{5}-0.02 X_{2} X_{5}+0.01 X_{3} X_{5}, \\
\widehat{\% \mathrm{O}_{2}}= & 1.23+0.03 X_{1}+0.02 X_{3}-0.05 X_{2}^{2}+0.03 X_{1} X_{2} \\
& -0.02 X_{1} X_{4}-0.04 X_{1} X_{5}-0.04 X_{3} X_{5}, \\
\widehat{\mathrm{O}_{2}{ }^{2-}}= & 0.73-0.12 X_{1}-0.08 X_{2}+0.17 X_{4}+0.04 X_{5} \\
& +0.04 X_{1}^{2}+0.05 X_{3}^{2}+0.06 X_{1} X_{4}+0.02 X_{1} X_{5} \\
& -0.05 X_{2} X_{5}-0.05 X_{3} X_{5}-0.09 X_{4} X_{5} .
\end{aligned}
$$

The proposed model equations were validated. The results revealed that the predicted as well as the experimental values corresponded well with each other (Table 7). 
TABLE 3: ANOVA for full quadratic models.

\begin{tabular}{|c|c|c|c|c|c|c|}
\hline Response & Source & SS & $\mathrm{DF}$ & MS & $F$ value & Significance \\
\hline \multirow{3}{*}{$\mathrm{Ca} / \mathrm{P}$} & Regression & 0.19852890 & 18 & 0.011029 & 27.3600 & $* * *$ \\
\hline & Residue & 0.00201560 & 5 & 0.000403 & - & - \\
\hline & Total & 0.20054450 & 23 & - & - & - \\
\hline \multirow{3}{*}{$\% \mathrm{O}_{2}$} & Regression & 0.15219041 & 18 & 0.008455 & 10.2974 & $* *$ \\
\hline & Residue & 0.00410543 & 5 & 0.000821 & - & - \\
\hline & Total & 0.15629583 & 23 & - & - & - \\
\hline \multirow{3}{*}{$\% \mathrm{O}_{2}{ }^{2-}$} & Regression & 12.365827 & 18 & 0.686990 & 34.9235 & $* * *$ \\
\hline & Residue & 0.098356 & 5 & 0.019671 & - & - \\
\hline & Total & 12.464183 & 23 & - & - & - \\
\hline
\end{tabular}

*** Significant on a level of $99.9 \%$; ${ }^{* *}$ significant on a level of $99 \%$.

TABLE 4: Model coefficient estimated by multiple linear of $\mathrm{Ca} / \mathrm{P}$ ratio response.

\begin{tabular}{|c|c|c|c|c|c|}
\hline Factor & Estimated coefficient & $\mathrm{DF}$ & SS & $F_{\exp }$ value & $P$ value \\
\hline Intercept & 1.5920365 & - & - & - & $<0.0001$ \\
\hline$X_{1}$ & 0.0593194 & 1 & 0.06502936 & 161.3150 & $<0.0001$ \\
\hline$X_{2}$ & 0.0376153 & 1 & 0.02614846 & 64.8651 & 0.0005 \\
\hline$X_{3}$ & 0.0468771 & 1 & 0.04061039 & 100.7401 & 0.0002 \\
\hline$X_{4}$ & 0.0149504 & 1 & 0.00393388 & 9.7586 & 0.0261 \\
\hline$X_{5}$ & 0.0123254 & 1 & 0.00267373 & 6.6326 & 0.0497 \\
\hline$X_{1} X_{2}$ & -0.022688 & 1 & 0.00823556 & 20.4295 & 0.0063 \\
\hline$X_{1} X_{3}$ & -0.008563 & 1 & 0.00117306 & 2.9100 & 0.1487 \\
\hline$X_{1} X_{4}$ & 0.0125556 & 1 & 0.00291335 & 7.2270 & 0.0434 \\
\hline$X_{1} X_{5}$ & -0.013819 & 1 & 0.00352934 & 8.7550 & 0.0316 \\
\hline$X_{2} X_{3}$ & 0.0120625 & 1 & 0.00232806 & 5.7751 & 0.0614 \\
\hline$X_{2} X_{4}$ & 0.0072597 & 1 & 0.00097398 & 2.4161 & 0.1808 \\
\hline$X_{2} X_{5}$ & -0.02051 & 1 & 0.00777381 & 19.2841 & 0.0071 \\
\hline$X_{3} X_{4}$ & -0.011373 & 1 & 0.00239035 & 5.9296 & 0.0590 \\
\hline$X_{3} X_{5}$ & 0.0128729 & 1 & 0.00306247 & 7.5969 & 0.0400 \\
\hline$X_{4} X_{5}$ & -0.010175 & 1 & 0.00182201 & 4.5198 & 0.0868 \\
\hline$X_{1} X_{1}$ & -0.022998 & 1 & 0.00250741 & 6.2200 & 0.0549 \\
\hline$X_{2} X_{2}$ & -0.024389 & 1 & 0.00281981 & 6.9949 & 0.0457 \\
\hline$X_{3} X_{3}$ & -0.057069 & 1 & 0.01543930 & 38.2995 & 0.0016 \\
\hline
\end{tabular}

TABle 5: Model coefficient estimated by multiple linear of $\% \mathrm{O}_{2}$ response.

\begin{tabular}{lccccc}
\hline Factor & $\begin{array}{c}\text { Estimated } \\
\text { coefficient }\end{array}$ & DF & SS & $\begin{array}{c}F_{\text {exp }} \\
\text { value }\end{array}$ & $P$ value \\
\hline Intercept & 1.2253689 & - & - & - & $<0.0001$ \\
$X_{1}$ & 0.0318049 & 1 & 0.01869415 & 22.7676 & 0.0050 \\
$X_{2}$ & 0.0059718 & 1 & 0.00065905 & 0.8027 & 0.4114 \\
$X_{3}$ & 0.0174539 & 1 & 0.00562993 & 6.8567 & 0.0472 \\
$X_{4}$ & -0.007055 & 1 & 0.00087599 & 1.0669 & 0.3490 \\
$X_{5}$ & 0.0054451 & 1 & 0.00052182 & 0.6355 & 0.4615 \\
$X_{1} X_{2}$ & 0.029375 & 1 & 0.01380625 & 16.8146 & 0.0093 \\
$X_{1} X_{3}$ & -0.000625 & 1 & 0.00000625 & 0.0076 & 0.9339 \\
$X_{1} X_{4}$ & -0.020555 & 1 & 0.00780817 & 9.5096 & 0.0274 \\
$X_{1} X_{5}$ & -0.035555 & 1 & 0.02336234 & 28.4530 & 0.0031 \\
$X_{2} X_{3}$ & 0.018125 & 1 & 0.00525625 & 6.4016 & 0.0525 \\
$X_{2} X_{4}$ & 0.0102782 & 1 & 0.00195233 & 2.3777 & 0.1837 \\
$X_{2} X_{5}$ & -0.006528 & 1 & 0.00078761 & 0.9592 & 0.3724 \\
$X_{3} X_{4}$ & -0.037546 & 1 & 0.02605225 & 31.7290 & 0.0024 \\
$X_{3} X_{5}$ & -0.006204 & 1 & 0.00071130 & 0.8663 & 0.3947 \\
$X_{4} X_{5}$ & -0.002055 & 1 & 0.00007432 & 0.0905 & 0.7756 \\
$X_{1} X_{1}$ & 0.0307836 & 1 & 0.00449227 & 5.4711 & 0.0665 \\
$X_{2} X_{2}$ & -0.052654 & 1 & 0.01314306 & 16.0069 & 0.0103 \\
$X_{3} X_{3}$ & -0.033185 & 1 & 0.00522065 & 6.3582 & 0.0531 \\
\hline
\end{tabular}

TABLE 6: Model coefficient estimated by multiple linear of $\% \mathrm{O}_{2}{ }^{2-}$ response.

\begin{tabular}{lccccc}
\hline Factor & $\begin{array}{c}\text { Estimated } \\
\text { coefficient }\end{array}$ & DF & SS & $\begin{array}{c}F_{\text {exp }} \\
\text { value }\end{array}$ & $P$ value \\
\hline Intercept & 1.3719791 & - & - & - & $<0.0001$ \\
$X_{1}$ & -0.328742 & 1 & 1.9972229 & 101.5298 & 0.0002 \\
$X_{2}$ & -0.118524 & 1 & 0.2596133 & 13.1976 & 0.0150 \\
$X_{3}$ & -0.345284 & 1 & 2.2032808 & 112.0049 & 0.0001 \\
$X_{4}$ & 0.3279447 & 1 & 1.8928547 & 96.2242 & 0.0002 \\
$X_{5}$ & 0.0116947 & 1 & 0.0024071 & 0.1224 & 0.7407 \\
$X_{1} X_{2}$ & 0.1425 & 1 & 0.3249000 & 16.5165 & 0.0097 \\
$X_{1} X_{3}$ & -0.13 & 1 & 0.2704000 & 13.7459 & 0.0139 \\
$X_{1} X_{4}$ & -0.218758 & 1 & 0.8843915 & 44.9585 & 0.0011 \\
$X_{1} X_{5}$ & -0.177508 & 1 & 0.5823078 & 29.6019 & 0.0028 \\
$X_{2} X_{3}$ & -0.155 & 1 & 0.3844000 & 19.5412 & 0.0069 \\
$X_{2} X_{4}$ & -0.092784 & 1 & 0.2194726 & 11.1570 & 0.0205 \\
$X_{2} X_{5}$ & 0.0202263 & 1 & 0.0075605 & 0.3843 & 0.5624 \\
$X_{3} X_{4}$ & -0.092784 & 1 & 0.1590980 & 8.0878 & 0.0361 \\
$X_{3} X_{5}$ & 0.1590342 & 1 & 0.4674095 & 23.7610 & 0.0046 \\
$X_{4} X_{5}$ & -0.045805 & 1 & 0.0369273 & 1.8772 & 0.2290 \\
$X_{1} X_{1}$ & 0.0127027 & 1 & 0.0007649 & 0.0389 & 0.8514 \\
$X_{2} X_{2}$ & -0.151392 & 1 & 0.1086509 & 5.5233 & 0.0655 \\
$X_{3} X_{3}$ & 0.2699695 & 1 & 0.3455077 & 17.5641 & 0.0086 \\
\hline
\end{tabular}


TABLE 7: Validation of the experimental design.

\begin{tabular}{lccccccccc}
\hline \multirow{2}{*}{ Order } & $\mathrm{Ca} /$ & $\mathrm{Ca} /$ & $e$ & $\%$ & $\%$ & $e$ & $\% \mathrm{O}_{2 \mathrm{ex}}^{2-}$ & $\% \mathrm{O}_{2 \mathrm{es}}^{2-}$ & $e$ \\
& $P_{\mathrm{ex}}$ & $P_{\text {es }}$ & $10^{3}$ & $\mathrm{O}_{2 \mathrm{ex}}$ & $\mathrm{O}_{2 \mathrm{es}}$ & $10^{2}$ & & & \\
\hline 1 & 1.351 & 1.356 & -5 & 1.10 & 1.10 & 0 & 1.42 & 1.36 & 6 \\
2 & 1.293 & 1.300 & -7 & 1.05 & 1.07 & -2 & 2.74 & 2.74 & 0 \\
3 & 1.347 & 1.353 & -6 & 1.07 & 1.07 & 0 & 1.07 & 1.02 & 5 \\
4 & 1.444 & 1.437 & 7 & 1.10 & 1.09 & 1 & 2.69 & 2.68 & 1 \\
5 & 1.384 & 1.391 & -7 & 0.89 & 0.91 & -2 & 1.25 & 1.22 & 3 \\
6 & 1.422 & 1.416 & 6 & 1.10 & 1.10 & 0 & 2.29 & 2.31 & -2 \\
7 & 1.570 & 1.576 & -6 & 1.10 & 1.11 & -1 & 1.14 & 1.19 & -5 \\
8 & 1.534 & 1.538 & -4 & 1.04 & 1.03 & 1 & 1.15 & 1.14 & 1 \\
9 & 1.442 & 1.446 & -4 & 1.10 & 1.10 & 0 & 1.32 & 1.36 & -4 \\
10 & 1.532 & 1.526 & 6 & 1.07 & 1.07 & 0 & 1.35 & 1.29 & 6 \\
11 & 1.580 & 1.585 & -5 & 1.13 & 1.13 & 0 & 0.71 & 0.68 & 3 \\
12 & 1.531 & 1.535 & -4 & 1.05 & 1.04 & 1 & 0.89 & 0.95 & -6 \\
13 & 1.425 & 1.430 & -5 & 1.07 & 1.07 & 0 & 1.29 & 1.38 & -9 \\
14 & 1.586 & 1.592 & -6 & 1.16 & 1.17 & -1 & 2.13 & 2.12 & 10 \\
15 & 1.571 & 1.575 & -4 & 1.28 & 1.28 & 0 & 0.48 & 0.57 & -9 \\
16 & 1.615 & 1.609 & 6 & 1.10 & 1.09 & 1 & 0.42 & 0.41 & 1 \\
17 & 1.420 & 1.407 & 12 & 1.10 & 1.08 & 2 & 1.47 & 0.86 & -8 \\
18 & 1.570 & 1.562 & 8 & 1.30 & 1.30 & 0 & 0.57 & 1.04 & 13 \\
19 & 1.529 & 1.519 & 9 & 1.08 & 1.08 & 0 & 0.67 & 0.76 & -9 \\
20 & 1.552 & 1.541 & 11 & 1.07 & 1.05 & 2 & 0.92 & 0.78 & 13 \\
21 & 1.478 & 1.465 & 13 & 1.13 & 1.10 & 3 & 2.81 & 2.82 & -1 \\
22 & 1.533 & 1.525 & 8 & 1.04 & 1.06 & -2 & 1.48 & 1.32 & 6 \\
23 & 1.570 & 1.572 & -2 & 1.13 & 1.14 & -1 & 1.53 & 1.55 & -2 \\
24 & 1.550 & 1.572 & -22 & 1.13 & 1.14 & -1 & 1.52 & 1.55 & -3 \\
\hline$e=y_{\text {exp }}$ & $-\hat{y}_{\text {cal }} \cdot$ & & & & & & & & \\
& & & & & & & & &
\end{tabular}

The dependent variable equations represent the surface responses as function of only those factors that have had significant influence on it.

The response surface contour plots to estimate the $\mathrm{Ca} / \mathrm{P}$ and $\% \mathrm{O}_{2}$ responses over independent variables $\mathrm{Ca} / \mathrm{P}_{r}$ and $\left[\mathrm{Ca}^{2+}\right]$ for values of $\mathrm{pH}=7.87 \quad\left(X_{1}=1.1592\right), \mathrm{T}=40^{\circ} \mathrm{C}$ $\left(X_{4}=-1\right)$, and $D=1 \mathrm{~h}\left(X_{5}=-1\right)$ are shown in Figures 1 and 2 . The contour plots given in figures show that when $\left[\mathrm{Ca}^{2+}\right]$ and $\mathrm{Ca} / \mathrm{P}_{r}$ increase simultaneously or when $\left[\mathrm{Ca}^{2+}\right]$ increases and the $\mathrm{Ca} / \mathrm{P}_{r}$ remains unchanged or conversely, the $\mathrm{Ca} / \mathrm{P}$ ratio and $\% \mathrm{O}_{2}$ of the precipitate increase until obtaining an optimum value, which remain unchanged in the experimental field and equalize to 1.6 for the $\mathrm{Ca} / \mathrm{P}$ response and $1.40 \%$ for the $\% \mathrm{O}_{2}$ response.

By analyzing the response surface contour plots of $\mathrm{Ca} / \mathrm{P}$ and $\% \mathrm{O}_{2}$, we note that the formation of an oxygenated apatite with $\mathrm{Ca} / \mathrm{P}$ equal to 1.575 and the most oxygenated (\% $\mathrm{O}_{2(\max )}=1.40 \%$ in the experimental field) can be done only in the arc intersection of the contour plot where the $\mathrm{Ca} / \mathrm{P}$ equals 1.575 with the isoresponse surface of the $\% \mathrm{O}_{2}$ optimum. This field corresponds to a concentration of calcium ions $\left[\mathrm{Ca}^{2+}\right]=0.631\left(X_{3}=1\right)$ and $\mathrm{Ca} / \mathrm{P}_{r}$ ratio between 1.513 $\left(X_{2}=0.1\right)$ and $1.622\left(X_{2}=0.96\right)$. However, in this field, we see that the $\% \mathrm{O}_{2}{ }^{2-}$ falls by moving into the higher ratios of $\mathrm{Ca} / \mathrm{P}_{r}$ (Figure 3). So, it was an interest in working with a minimal $\mathrm{Ca} / \mathrm{P}_{r}$. Therefore, the optimal conditions for obtaining an oxygenated apatite, with the above criteria, are as follows: $\mathrm{pH}=7.87, \mathrm{Ca} / \mathrm{P}_{r}=1.513,\left[\mathrm{Ca}^{2+}\right]=0.631 \mathrm{M}, \mathrm{T}=40^{\circ} \mathrm{C}$, and $D=1 \mathrm{~h}$. Under these conditions, the values of the predicted responses; $\mathrm{Ca} / \mathrm{P}, \% \mathrm{O}_{2}$, and $\% \mathrm{O}_{2}{ }^{2-}$, for the oxygenated apatite

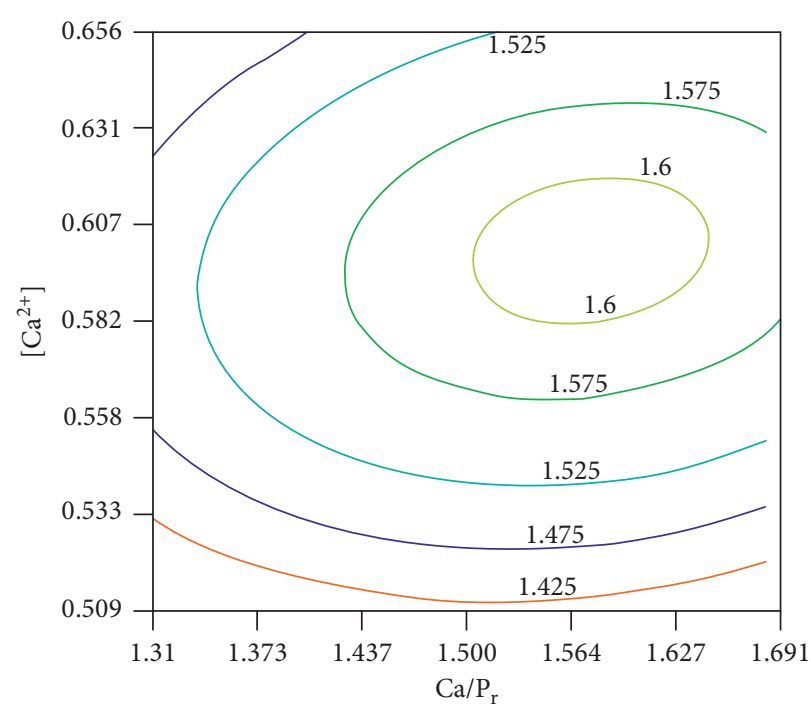

Figure 1: Isoresponse contour plot for $\mathrm{Ca} / \mathrm{P}$ with $\mathrm{pH}=7.87$, $\mathrm{T}=40^{\circ} \mathrm{C}$, and $D=1 \mathrm{~h}$.

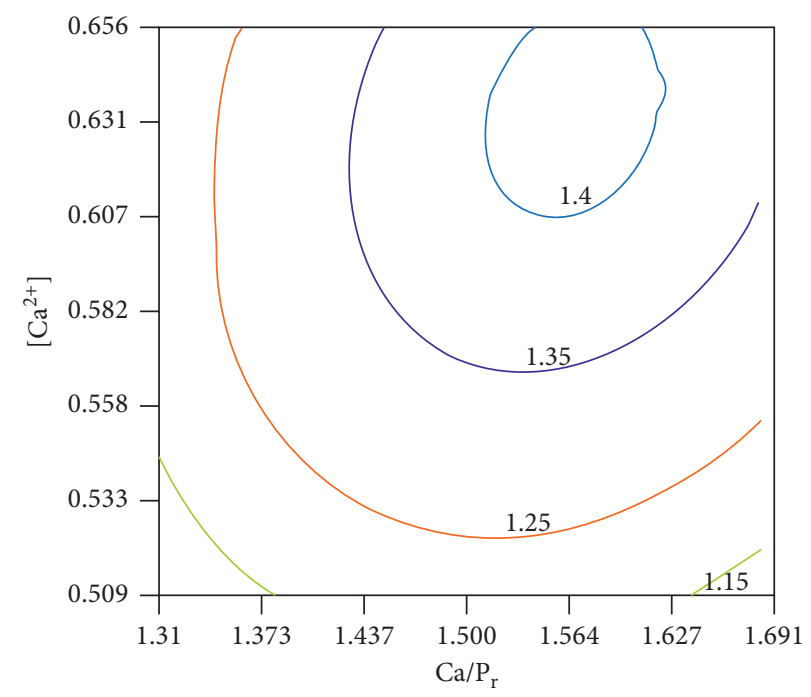

FIgURE 2: Isoresponse contour plot for $\% \mathrm{O}_{2}$ with $\mathrm{pH}=7.87$, $\mathrm{T}=40^{\circ} \mathrm{C}$, and $D=1 \mathrm{~h}$.

synthesis from calcium chloride and phosphoric acid are, respectively, as follows: $1.575,1.40 \%$, and $0.79 \%$.

The experimental verification in the optimum conditions of synthesis gave a phosphocalcic oxygenated apatite with $\mathrm{Ca} / \mathrm{P}$ ratio, $\% \mathrm{O}_{2}$, and $\% \mathrm{O}_{2}{ }^{2-}$ equal to $1.577 \approx 1.575,1.39 \%$, and $0.77 \%$, respectively. X-Ray diffraction analysis (Figure 4 ) indicates that this product is an amorphous apatite, similar to that of the mineral part of the bone [14], since it was prepared under temperature and $\mathrm{pH}$ conditions close to biomimetic conditions and for only one hour. The infrared spectrum of this product (Figure 5) reveals only the band characteristic of nonstoichiometric apatites (attributable to $\mathrm{PO}_{4}{ }^{3-}$ and $\mathrm{HPO}_{4}{ }^{2-}$ ions) more the band characteristics of the presence of water [14]. 


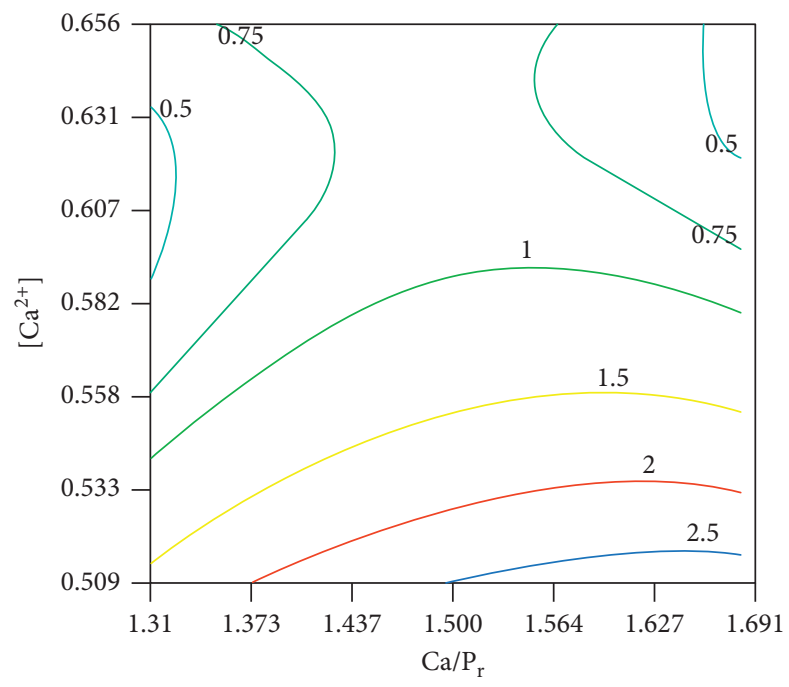

FIgURE 3: Isoresponse contour plot for $\% \mathrm{O}_{2}{ }^{2-}$ with $\mathrm{pH}=7.87, \mathrm{~T}=40^{\circ} \mathrm{C}$, and $D=1 \mathrm{~h}$.

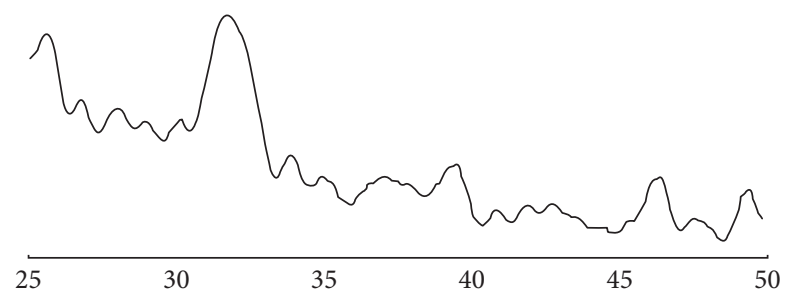

FIGURE 4: X-ray diffraction diagram of the obtained precipitate under optimum conditions.

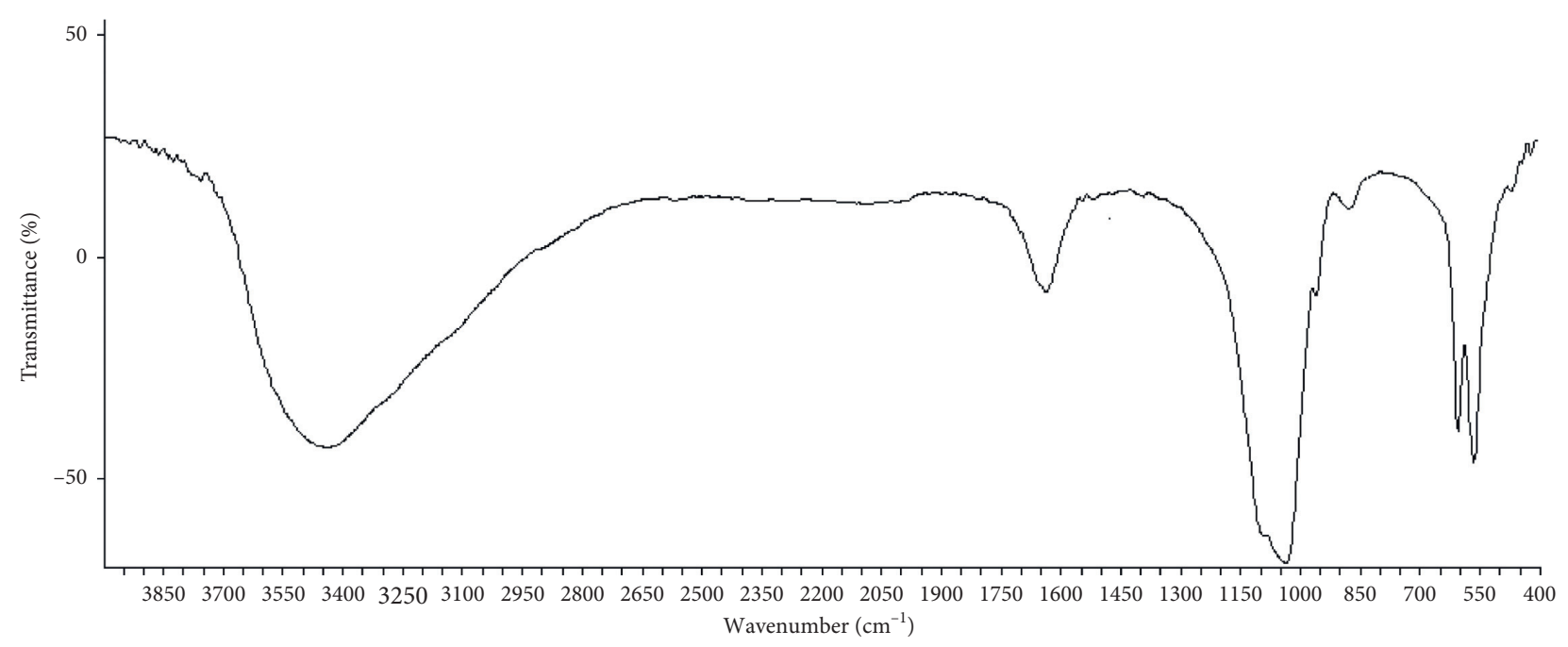

FIGURE 5: Infrared spectrum of the obtained precipitate under optimum conditions.

\section{Conclusion}

This work points out the variability of the chemical composition $\left(\mathrm{Ca} / \mathrm{P}\right.$ molar ratio, $\% \mathrm{O}_{2}$, and $\% \mathrm{O}_{2}{ }^{2-}$ ) of phosphocalcic oxygenated apatite precipitated from aqueous media $\left(\mathrm{CaCl}_{2}, \mathrm{H}_{3} \mathrm{PO}_{4}, \mathrm{H}_{2} \mathrm{O}_{2}\right.$, and $\left.\mathrm{NH}_{4} \mathrm{OH}\right)$ with the experimental synthesis conditions $\left(\mathrm{pH}, \mathrm{Ca} / \mathrm{P}_{r},\left[\mathrm{Ca}^{2+}\right], \mathrm{T}\right.$, and $D)$. A central composite design was successfully employed for the experimental design and analysis of results, and the graphic response surfaces and contour plots were used to locate the optimum conditions $\left(\mathrm{pH}=7.87, \mathrm{Ca} / \mathrm{P}_{r}=1.513\right.$, $\left[\mathrm{Ca}^{2+}\right]=0.631 \mathrm{M}, \mathrm{T}=40^{\circ} \mathrm{C}$, and $\mathrm{D}=1 \mathrm{~h}$ ) of the synthesis of 
phosphocalcic oxygenated apatite with $\mathrm{Ca} / \mathrm{P}$ ratio, $\% \mathrm{O}_{2}$, and $\% \mathrm{O}_{2}{ }^{2-}$ equal to $1.577 \approx 1.575,1.39 \%$, and $0.77 \%$, respectively.

\section{Data Availability}

No data were used to support this study.

\section{Conflicts of Interest}

The authors declare that they have no conflicts of interest.

\section{References}

[1] C. Ledard, E. Benque, J. L. Lacout, and C. Rey, "Bony or dental filling biomaterials and processes for preparation thereof," U.S. Patent N 5,141,561, 1992.

[2] C. Rey, "Etude des relations entre apatites et composes moleculaires," INP, Toulouse, France, Thèse, 1984.

[3] H. Chaair, S. Belouafa, K. Digua, B. Sallek, A. Essaadani, and M. Elmajdoubi, "Apatites antiseptiques et leur procédé de préparation," N de brevet: 30308, 2009.

[4] D. D. Lee, C. Rey, and M. Aiolova, "Synthesis of reactive amorphous calcium phosphates," U.S. Patent N 5,683,461, 1997.

[5] S. Belouafa, F. E. Faouzi, B. Sallek et al., "Etude de l'influence des paramètres de synthèse sur la composition chimique des apatites oXygénées carbonatées," Journal of Phosphorus Sulfur and Silicone, vol. 189, pp. 1-8, 2014.

[6] H. Chaair, S. Belouafa, K. Digua, B. Sallek, H. Oudadesse, and L. Mouhir, "Advanced statistical optimization of parameters of synthesis process of oxygenated carbonated apatite," Phosphorus, Sulfur, and Silicon and the Related Elements, vol. 183, no. 11, pp. 2752-2768, 2008.

[7] J. S. Montgomery and Y. Diseño, Análisis de Experimentos, Editora Panamericana S.A., Mexico City, Mexico, 1991.

[8] J. L. Meyer and E. D. Eanes, "The inhibition of calcium oxalate crystal growth by multidentate organic phosphonates," Calcified Tissue Research, vol. 23, p. 259, 1977.

[9] A. Gee and V. R. Dietz, Analytical Chemistry, vol. 25, p. 1320, 1954.

[10] J. C. Trombe and G. Montel, "Some features of the incorporation of oxygen in different oxidation states in the apatitic lattice-I on the existence of calcium and strontium oxyapatites," Journal of Inorganic and Nuclear Chemistry, vol. 40, no. 1, pp. 15-21, 1978.

[11] SAS Institute, JMP Statistic and Graphics Guide and User's Guide (Version 3.1), SAS Institute, Cary, NC, USA, 1995.

[12] R. M. Bethea, B. S. Duran, and T. L. Boullion, Statistical Methods for Engineers and Scientists, Marcel Dekker, New York, NY, USA, 1975.

[13] R. G. Brereton, Chemometrics Applications of Mathematics and Statistics to Laboratory Systems, Ellis Horwood Limited, England, UK, 1990.

[14] J. C. Heughebaert, “Contribution à l'étude de l'évolution des orthophosphates de calcium précipités amorphes en orthophosphates apatitiques," Institut National Polytechnique de Toulouse, Toulouse, France, Thèse de Doctorat, 1977. 